\title{
Isolation and structure elucidation of tumescenamides A and B, two peptides produced by Streptomyces tumescens YM23-260
}

\author{
Keiichiro Motohashi ${ }^{1}$, Takashi Toda ${ }^{1}$, Masayuki Sue ${ }^{1}$, Kazuo Furihata ${ }^{2}$, Yoshikazu Shizuri ${ }^{3}$, \\ Yoshihide Matsuo ${ }^{4,7}$, Hiroaki Kasai ${ }^{3}$, Kazuo Shin-ya ${ }^{5}$, Motoki Takagi $^{5}$, Miho Izumikawa ${ }^{5}$, \\ Yukio Horikawa ${ }^{6}$ and Haruo Seto ${ }^{1}$
}

Two peptides, tumescenamides A and B, were isolated from the fermentation broth of a marine bacterium, Streptomyces tumescens YM23-260. The structure of tumescenamide A was determined to be a cyclic depsipeptide consisting of $\alpha$-amino-2butenoic acid, tyrosine, valine, leucine and threonine, substituted with a 2,4-dimethylheptanoyl residue at the $\alpha-\mathrm{NH}_{2}$ position. Tumescenamide $B$ possesses a 2,4,6-trimethylnonanoyl residue in place of the 2,4-dimethylheptanoyl substituent in tumescenamide A. Tumescenamide $A$ induced reporter gene expression under the control of the insulin-degrading enzyme promoter.

The Journal of Antibiotics (2010) 63, 549-552; doi:10.1038/ja.2010.73; published online 7 July 2010

Keywords: insulin-degrading enzyme; pentapeptide; Streptomyces tumescens; tumescenamide

\section{INTRODUCTION}

Terpenoids are the largest family of compounds found in nature with over 24000 known examples and are mainly produced by fungi and plants. Production of these compounds by actinomycetes including Streptomyces, however, was rather rare, and only limited numbers of compounds were reported to date. ${ }^{1}$ In view of the excellent ability of Streptomyces to produce many kinds of bioactive secondary metabolites with structural diversity, this phenomenon seemed to be interesting for us.

Being stimulated in this phenomenon, we started screening for terpenoids produced by actinomycetes and succeeded in the isolation of oxaloterpins ${ }^{2}$ and napyradiomycin analogs. ${ }^{3}$ Our strategy for screening of terpenoids in these cases was as follows: (1) prepare a lipophilic fraction from the fermentation broth of actinomycetes by EtOAc extraction, (2) analyze by TLC development followed by colorization with vanillin- $\mathrm{H}_{2} \mathrm{SO}_{4}$. Select the spots that change to bright purple or violet, (3) analyze fractions corresponding to these spots by NMR and (4) select fractions showing methyl singlets at ca. $\delta_{\mathrm{H}} 1.0$ as candidates for terpenoids. ${ }^{2}$ This strategy, however, was not efficient as many of the selected fractions did not show the expected NMR features.

To carry out more efficient screening of terpenoids, we started using liquid chromatography NMR (LC-NMR) that enabled to detect compounds with several methyl groups without amenable to tedious procedures. During this screening process, we noticed that this method enabled to detect polyketides and peptides that showed strong methyl doublets at around $\delta_{\mathrm{H}}$ 1.0.

Here, we describe isolation aided by LC-NMR of the two new peptides, tumescenamides A and B, produced by Streptomyces tumescens YM23-260, and their structural elucidation.

\section{RESULTS AND DISCUSSION}

Fermentation, extraction and isolation

Several actinomycetes strains were cultured at $28^{\circ} \mathrm{C}$ for 7 days by rotary shaking in $500 \mathrm{ml}$ baffled Erlenmeyer flasks each containing $100 \mathrm{ml}$ of the production medium. The filtrate of each fermentation broth was extracted with EtOAc and the residual oily material obtained after removal of the solvent was analyzed by LC-NMR (ODS column, $70 \% \mathrm{CH}_{3} \mathrm{CN}$ and $30 \% \mathrm{D}_{2} \mathrm{O}$ ) to check for the presence of methyl signals at around $\delta_{\mathrm{H}} 0$ in the ${ }^{1} \mathrm{H}-\mathrm{NMR}$ spectrum.

A sample prepared from $S$. tumescens YM23-260 showed an LC peak $\left(t_{\mathrm{R}}=5.2 \mathrm{~min}\right)$, which contained a substance showing the presence of nine methyl doublet signals at $\delta_{\mathrm{H}} 0.4-1.6$ (Figure 1). Additional signals at $\delta_{\mathrm{H}} 4-5$ ascribed to the $\alpha$-methine signals of amino acids suggested that this LC peak was because of a peptide. In addition, a

\footnotetext{
${ }^{1}$ Bioregulatory Lab, Faculty of Applied Bioscience, Tokyo University of Agriculture, Setagaya-ku, Tokyo, Japan; ${ }^{2}$ Laboratory of Analytical Chemistry, Department of Applied Biological Chemistry, Graduate School of Agricultural and Life Sciences, University of Tokyo, Bunkyo-ku, Tokyo, Japan; ${ }^{3}$ MBI chair, 'Marine Biosciences', Kamaishi Research Laboratory, Kitasato University, Heita, Kamaishi, Iwate, Japan; ${ }^{4}$ Marine Biotechnology Institute, Heita, Kamaishi-shi, Iwate, Japan; 5 Biomedicinal Information Research Center (BIRC), Japan Biological Informatics Consortium (JBIC), Aomi, Koto-ku, Tokyo, Japan and ${ }^{6}$ Internal Medicine III, Department of Diabetes and Endocrinology, Gifu University, Graduate School of Medicine, Yanagido, Gifu-shi, Gifu, Japan

${ }^{7}$ Current address: Suntory Holdings Limited, R\&D Planning Division, Wakayamadai, Shimamoto-cho, Mishima-gun, Osaka 618-8503, Japan Correspondence: Professor H Seto, Faculty of Applied Bioscience, Tokyo University of Agriculture, 1-1-1, Sakuragaoka, Setagaya-ku, Tokyo 156-8502, Japan. E-mail: haseto@nodai.ac.jp
}

Received 11 April 2010; revised 20 May 2010; accepted 2 June 2010; published online 7 July 2010 


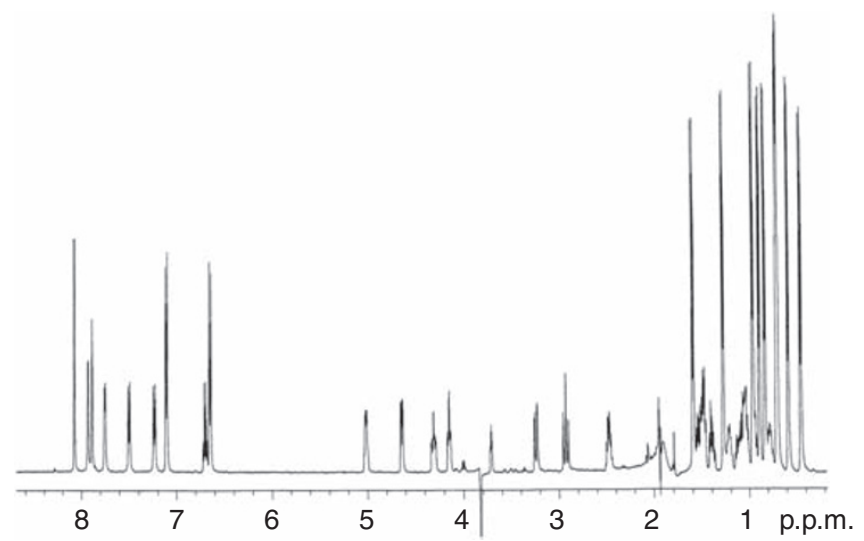

Figure 1 LC-NMR spectrum of EtOAc extract of the fermentation broth of Streptomyces tumescens. Retention time $=5.2 \mathrm{~min}$. ODS column, $70 \%$ $\mathrm{CH}_{3} \mathrm{CN}$ and $30 \% \mathrm{D}_{2} \mathrm{O}$. The strong peak at $\delta_{\mathrm{H}} 1.9$ is because of the residual suppression peak of the solvent.

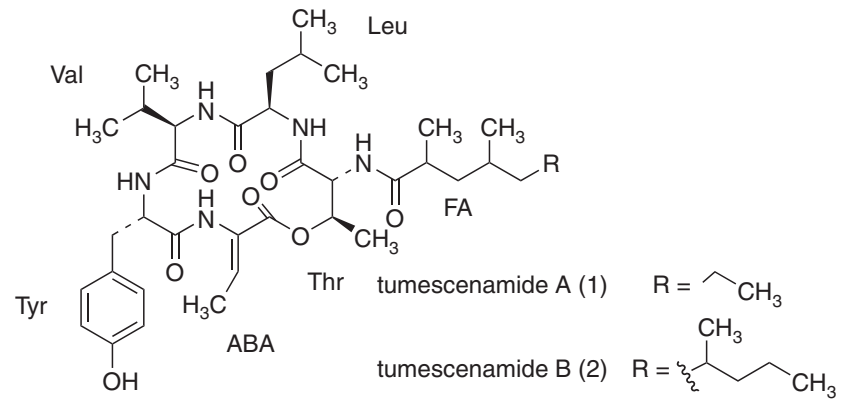

Figure 2 Structures of tumescenamides A (1) and B (2).

pair of aromatic doublet signals at $\delta_{\mathrm{H}} 6.6$ and 7.1 (each $2 \mathrm{H}$ ) indicated the presence of a $p$-substituted aromatic ring presumably owing to a tyrosine residue.

These data implied that this LC peak might contain a new metabolite. In addition to this peak, another LC peak $\left(t_{\mathrm{R}}=7.9 \mathrm{~min}\right)$ showed similar NMR signals. Thus we carried out their large-scale purification as follows. The crude EtOAc extract prepared as described above from 41 of the fermentation broth was subjected to silica gel column chromatography and C-18 reverse-phase HPLC yielding a major component $(15 \mathrm{mg})$ and a minor component $(0.6 \mathrm{mg})$.

Two-dimensional NMR studies of these compounds by COSY, heteronuclear single-quantum coherence and constant-time heteronuclear multiple bond correlation (CT-HMBC) ${ }^{4}$ as well as by HR-MS and IR measurements proved them to be new peptides as expected, and they were designated as tumescenamides A (1) and B (2) (Figure 2).

\section{Structure elucidation}

Compound 1 was isolated as a white powder $\left([\alpha]^{25}{ }_{D}+30, c 0.65\right.$, $\mathrm{MeOH})$. The HRFAB-MS spectrum of 1 established its molecular formula as $\mathrm{C}_{37} \mathrm{H}_{57} \mathrm{~N}_{5} \mathrm{O}_{8}\left(\mathrm{~m} / z 700.4248[\mathrm{M}+\mathrm{Na}]^{+}\right.$, calcd. 700.4279). Its peptide structure was clarified by the ${ }^{1} \mathrm{H}-\mathrm{NMR},{ }^{13} \mathrm{C}-\mathrm{NMR}$ and heteronuclear single-quantum coherence spectra recorded in acetone- $d_{6}$ (Table 1) (Supplementary Figures S1-S6). Diagnostic resonances for five carbonyl carbons $\left(\delta_{\mathrm{C}} 176.6\right.$ (Leu-1), 171.3 (Thr-1), 171.2 (Val-1), 169.5 (Tyr-1), 165.3 ( $\alpha$-amino-2-butenoic acid (ABA))) and four $\alpha$-amino methine protons and carbons $\left(\delta_{\mathrm{H}} 3.85 / \delta_{\mathrm{C}} 61.7\right.$, $4.45 / 56.7,4.92 / 55.5$, and $4.29 / 54.4)$, indicated the peptide structure
Table 1 NMR data for tumescenamide A (1) $\left(500 \mathrm{MHz}\right.$, acetone- $\left.d_{6}\right)$

\begin{tabular}{|c|c|c|c|c|}
\hline \multicolumn{3}{|c|}{ Position } & \multirow{2}{*}{$\frac{\delta_{C}}{171.3}$} & \multirow[t]{2}{*}{$\delta_{H}(\mathrm{~J}$ in $\mathrm{Hz})$} \\
\hline Thr & 1 & C & & \\
\hline & 2 & $\mathrm{CH}$ & 55.5 & $4.92(d, 9.0,3.2)$ \\
\hline & 3 & $\mathrm{CH}$ & 75.1 & $5.15(\mathrm{dq}, 3.2,6.1)$ \\
\hline & 4 & $\mathrm{CH}_{3}$ & 16.2 & $1.34(\mathrm{~d}, 6.4)$ \\
\hline & $\mathrm{NH}$ & & & $7.04(d, 9.0)$ \\
\hline \multirow[t]{5}{*}{ ABA } & 1 & C & 165.3 & \\
\hline & 2 & C & 128.0 & \\
\hline & 3 & $\mathrm{CH}$ & 134.8 & $6.57(q, 7.1)$ \\
\hline & 4 & $\mathrm{CH}_{3}$ & 14.7 & $1.67(d, 7.1)$ \\
\hline & $\mathrm{NH}$ & & & $7.98(\mathrm{~s})$ \\
\hline \multirow[t]{11}{*}{ Tyr } & 1 & $\mathrm{C}$ & 169.5 & \\
\hline & 2 & $\mathrm{CH}$ & 56.7 & $4.45(\mathrm{~m})$ \\
\hline & 3 & $\mathrm{CH}_{2}$ & 36.6 & $2.99(\mathrm{dd}, 13.7,13.7)$ \\
\hline & & & & $3.29(\mathrm{dd}, 3.4,13.9)$ \\
\hline & 4 & $\mathrm{C}$ & 130.0 & \\
\hline & 5 & $\mathrm{CH}$ & 130.9 & $7.19(\mathrm{~d}, 8.4)$ \\
\hline & 6 & $\mathrm{CH}$ & 115.8 & $6.71(d, 8.4)$ \\
\hline & 7 & C & 156.8 & \\
\hline & $\mathrm{NH}$ & & & \\
\hline & $\mathrm{OH}$ & & $7.48(d, 8.6)$ & \\
\hline & & & $8.20(\mathrm{br} \mathrm{s})$ & \\
\hline \multirow[t]{6}{*}{ Val } & 1 & C & 171.2 & \\
\hline & 2 & $\mathrm{CH}$ & 61.7 & $3.85(\mathrm{dd}, 3.9,3.9)$ \\
\hline & 3 & $\mathrm{CH}$ & $29.2^{\mathrm{a}}$ & $2.12(\mathrm{~m})$ \\
\hline & 4 & $\mathrm{CH}_{3}$ & 19.2 & $0.86(d, 7.1)$ \\
\hline & 5 & $\mathrm{CH}_{3}$ & 17.0 & $0.58(d, 7.1)$ \\
\hline & $\mathrm{NH}$ & & & $8.02(d, 3.9)$ \\
\hline \multirow[t]{7}{*}{ Leu } & 1 & C & 176.6 & \\
\hline & 2 & $\mathrm{CH}$ & 54.4 & $4.29(\mathrm{dd}, 7.6,7.6)$ \\
\hline & 3 & $\mathrm{CH}_{2}$ & 40.7 & $1.52,1.58(\mathrm{~m})$ \\
\hline & 4 & $\mathrm{CH}$ & 25.2 & $1.72(\mathrm{~m})$ \\
\hline & 5 & $\mathrm{CH}_{3}$ & 22.5 & $0.88(d, 7.1)$ \\
\hline & 6 & $\mathrm{CH}_{3}$ & 22.9 & $0.98, d(6.6)$ \\
\hline & $\mathrm{NH}$ & & & $7.92(\mathrm{br} \mathrm{d}, 2.0)$ \\
\hline \multirow[t]{9}{*}{ FA } & 1 & C & 177.3 & \\
\hline & 2 & $\mathrm{CH}$ & 39.1 & $2.65(\mathrm{~m})$ \\
\hline & 3 & $\mathrm{CH}_{2}$ & 42.7 & $1.67,1.02(\mathrm{~m})$ \\
\hline & 4 & $\mathrm{CH}$ & 31.0 & $1.38(\mathrm{~m})$ \\
\hline & 5 & $\mathrm{CH}_{2}$ & 39.9 & $0.92,1.14(\mathrm{~m})$ \\
\hline & 6 & $\mathrm{CH}_{2}$ & 20.6 & $1.18,1.20(\mathrm{~m})$ \\
\hline & 7 & $\mathrm{CH}_{3}$ & 14.6 & $0.78(t, 7.1)$ \\
\hline & $2-M e$ & $\mathrm{CH}_{3}$ & 19.1 & $1.04(\mathrm{~d}, 6.8)$ \\
\hline & 4-Me & $\mathrm{CH}_{3}$ & 20.2 & $0.76(\mathrm{~d}, 6.6)$ \\
\hline
\end{tabular}

Abbreviations: ABA, $\alpha$-amino-2-butenoic acid; FA, fatty acid; Leu, leucine; Thr, threonine; Tyr, tyrosine; Val, valine.

aBecause of overlapping of the solvent peak, this value was obtained by analysis of the HSQC spectrum.

of $\mathbf{1}$. Further structural information on $\mathbf{1}$ was obtained by analyzing heteronuclear single-quantum coherence, DEPT, CT-HMBC and COSY spectra (Supplementary Figures S7 and S8) resulting in the construction of six partial structures: threonine (Thr), valine (Val), leucine (Leu), tyrosine (Tyr), ABA and a fatty-acid (FA) side chain.

The structure of the FA moiety was straightforwardly determined to be 2,4-dimethylheptanoic acid by analysis of its CT-HMBC spectrum as shown in Figure 3. Interestingly, this simple branched FA has never been isolated from the nature. The amino-acid constituents of $\mathbf{1}$ and FA were then connected on the basis of COSY, CT-HMBC and NOESY correlations (Figure 4; Supplementary Figure S9). 


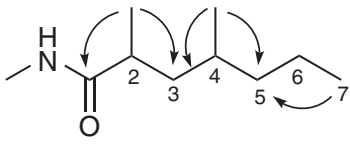

tumescenamide $A(1)$

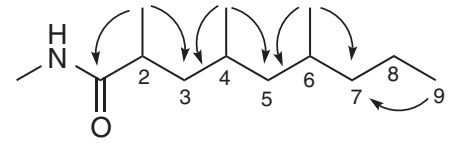

tumescenamide B (2)
Figure 3 Structures of the FA moiety of tumescenamides A (1) and B (2).

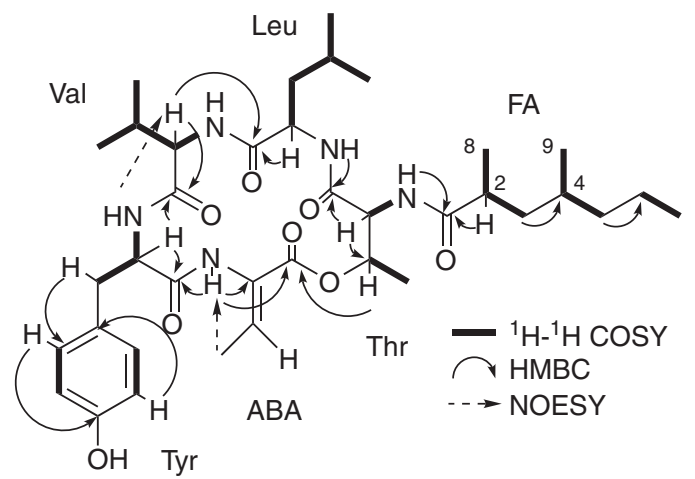

Figure 4 Important COSY, CT-HMBC and NOESY correlations observed for tumescenamide $\mathrm{A}(\mathbf{1})$.

The linkage of ABA to Tyr was established by CT-HMBC correlations from the $\mathrm{NH}$ amide proton of $\mathrm{ABA}\left(\delta_{\mathrm{H}}: 7.98\right)$ and the $\alpha$-amino proton of Tyr $\left(\mathrm{H}-2, \delta_{\mathrm{H}}: 4.45\right)$ to the Tyr amide carbonyl carbon $(\mathrm{C}-1$, $\left.\delta_{\mathrm{C}}: 169.5\right)$. The $\mathrm{Z}$ configuration of $\mathrm{ABA}$ was clarified by an NOE between the methyl and amide protons of ABA. The $\alpha$-amino proton of Tyr $\left(\mathrm{H}-2, \delta_{\mathrm{H}}: 4.45\right)$ and the $\alpha$-amino proton of Val $\left(\mathrm{H}-2, \delta_{\mathrm{H}}: 3.85\right)$ were correlated to the carbonyl carbon of $\mathrm{Val}\left(\mathrm{C}-1, \delta_{\mathrm{C}}: 171.2\right)$ by the CT-HMBC spectrum. A NOESY cross-peak between the NH of Tyr $\left(\delta_{\mathrm{H}}: 7.48\right)$ and the $\alpha$-amino proton of Val ( $\left.\mathrm{H}-2\right)$ also supported the sequence of Tyr-Val. The connection between Val and Leu was determined through interpretation of CT-HMBC data, which showed correlations from the $\alpha$-amino proton of $\mathrm{Val}\left(\mathrm{H}-2, \delta_{\mathrm{H}}\right.$ : 3.85) and the $\alpha$-amino proton of Leu $\left(\mathrm{H}-2, \delta_{\mathrm{H}}: 4.29\right)$ to the Leu amide carbonyl carbon $\left(\mathrm{C}-1, \delta_{\mathrm{C}}: 176.6\right)$. The NOESY correlation between the amide $\mathrm{NH}$ proton of Val $\left(\delta_{\mathrm{H}}: 8.02\right)$ and the $\alpha$-amino proton of Leu (H-2) also confirmed this connectivity. The subsequent connection of Leu to Thr was achieved on the basis of CT-HMBC correlations from the NH of Leu $\left(\delta_{\mathrm{H}}: 7.92\right)$ and the $\alpha$-amino proton of Thr $\left(\mathrm{H}-2, \delta_{\mathrm{H}}: 4.92\right)$ to the Thr amide carbonyl $\left(\mathrm{C}-1, \delta_{\mathrm{C}}: 171.3\right)$. This connectivity was also supported by the presence of a NOESY correlation between the amide $\mathrm{NH}$ proton of Leu $\left(\delta_{\mathrm{H}}: 7.92\right)$ and the $\alpha$-amino proton of Thr $(\mathrm{H}-2$, $\delta_{\mathrm{H}}$ : 4.92). Further, CT-HMBC correlations from the FA proton $(\mathrm{H}-2$, $\left.\delta_{\mathrm{H}}: 2.65\right)$ and the amide $\mathrm{NH}$ proton of $\mathrm{Thr}\left(\delta_{\mathrm{H}}: 7.04\right)$ to the $\mathrm{FA}$ carbonyl carbon (C-1, $\left.\ddot{a}_{\mathrm{C}}: 177.3\right)$ led to the assignment of Thr to FA linkage. A NOESY correlation was also observed between these protons. Finally, location of the ester linkage was established by the observation of CT-HMBC correlation from Thr $\left(\mathrm{H}-3, \delta_{\mathrm{H}}: 5.15\right)$ to ABA $\left(\mathrm{C}-1, \delta_{\mathrm{C}}: 165.3\right)$ completing the full planar structure of 1 .

The relative stereochemistry of FA was determined by $J$-based configurational analysis using ${ }^{3} \mathrm{~J}_{\mathrm{H}-\mathrm{H}}$ and ${ }^{3} \mathrm{~J}_{\mathrm{C}-\mathrm{H}}$ (Figure 5). ${ }^{5,6}$ For this experiment, we used $J$-resolved $\mathrm{HMBC}^{7}$ for efficient measurements (Supplementary Figure S10). Both the methyl carbon at $\mathrm{C}-2$ and $\mathrm{H}-2$ exhibited small three-bond couplings with $\mathrm{H}_{\mathrm{b}}-3$ $\left(J_{\mathrm{CH} 3(2)-\mathrm{Ha} 3}=3.3 \mathrm{~Hz}, J_{\mathrm{H} 2-\mathrm{H} 3 \mathrm{~b}}=5.4 \mathrm{~Hz}\right)$ and thus they were required to be gauche to $\mathrm{H}_{\mathrm{b}}-3$. Anti orientations between $\mathrm{H}_{\mathrm{a}}-3$ and $\mathrm{H}-2$ and between $\mathrm{H}_{\mathrm{b}}-3$ and $\mathrm{C}-1$ were determined from the large three-bond

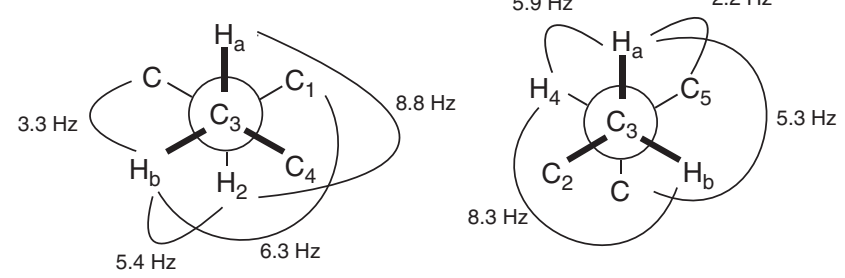

Figure $5 \mathrm{~J}$-based configurational analysis of FA at C-2 and C-4.

couplings $\left(J_{\mathrm{Ha} 3-\mathrm{H} 2}=8.8 \mathrm{~Hz}, J_{\mathrm{Hb} 3-\mathrm{Cl}}=6.3 \mathrm{~Hz}\right)$. Both $\mathrm{H}-4$ and $\mathrm{C}-5$ exhibited small three-bond couplings with $\mathrm{H}_{\mathrm{a}}-3\left(J_{\mathrm{H} 4-\mathrm{Ha} 3}=5.9 \mathrm{~Hz}\right.$, $J_{\mathrm{C} 5-\mathrm{Ha} 3}=2.2 \mathrm{~Hz}$ ) and were required to be gauche to $\mathrm{H}_{\mathrm{a}}-3$. Antiorientations between $\mathrm{H}_{\mathrm{a}}-3$ and methyl at $\mathrm{C}-4$ and between $\mathrm{H}_{\mathrm{b}}-3$ and $\mathrm{H}-4$ were determined from the large three-bond couplings $\left(J_{\mathrm{Ha} 3-\mathrm{CH} 3(4)}=5.3 \mathrm{~Hz}, J_{\mathrm{Hb} 3-\mathrm{H} 4}=8.3 \mathrm{~Hz}\right)$. These relationships assigned the relative stereochemistry of FA to $2 R^{*}, 4 R^{*}$ as shown in Figure 5.

Hydrolysis of 1 using $6 \mathrm{~N} \mathrm{HCl}$ yielded a mixture of free amino acids. The hydrolysis product was derivatized using the Marfey reagent ${ }^{8}$ and analyzed by HPLC. Comparison with the retention times of authentic Marfey standards of L- and D-forms of Thr, Tyr, Leu and Val showed that the absolute configurations of these amino acids were L-Thr, D-Tyr, L-Leu and L-Val. The absolute stereochemistry of the FA remained to be determined.

Tumescenamide B (2) was obtained as a white powder, which analyzed for the molecular formula $\mathrm{C}_{40} \mathrm{H}_{63} \mathrm{~N}_{5} \mathrm{O}_{8}$ by the HRFAB-MS $\left([\mathrm{M}+\mathrm{H}]^{+} \mathrm{m} / \mathrm{z}\right.$ 742.4756, calcd. 742.4755). The ${ }^{1} \mathrm{H}$ - and ${ }^{13} \mathrm{C}-\mathrm{NMR}$ spectral data of the amino-acid moiety of 2 were completely identical with those of 1 (see Experimental procedure) suggesting that the structural difference between them resided in the FA moiety (Supplementary Figures S11-S13). The molecular formula of $\mathbf{2}$ and its ${ }^{13} \mathrm{C}$-NMR spectral data indicated that 2 has additional carbons, $\mathrm{CH}_{3}$ $\left(\delta_{\mathrm{C}} 21.0\right), \mathrm{CH}_{2}(40.0)$ and $\mathrm{CH}$ (28.2). Its COSY and CT-HMBC spectra proved the structure of the FA moiety to be 2,4,6-trimethylnonanoic acid as shown in Figure 3 (Supplementary Figures S14-S16).

\section{Biological activity}

Tested so far, 1 showed weak activity only in the luciferase-reporter assay system, which enabled to observe the expression of insulindegrading enzyme (IDE). This enzyme, a metalloprotease enzyme responsible for insulin degradation, had been shown to have a key role in $\beta$-amyloid $(\mathrm{A} \beta)$ peptide degradation both in vitro and in vivo, and was selective for $A \beta$ monomer. ${ }^{9-11}$ Thus, substances which induce the upregulation of IDE enzyme are expected to be promising drugs for the treatment of Alzheimer's disease. Compound 1 induced reporter gene expression under the control of the IDE promoter more than three times at a concentration of $100 \mu \mathrm{M}$.

\section{EXPERIMENTAL PROCEDURE}

\section{General experimental procedures}

Optical rotations were recorded on a Jasco DIP-140 polarimeter (Jasco, Tokyo, Japan). UV and IR spectra were recorded on a Hitachi U-3310 spectrophotometer (Hitachi, Ibaraki, Japan) and a Shimadzu 8300 FTIR spectrometer (Shimadzu, Kyoto, Japan), respectively. LC-NMR was carried out on a Varian Inova 500 equipped with a cryo probe (Varian, Palo Alto, CA, USA). The HPLC condition of LC-NMR was as follows: Senshu Pak Pegasil ODS column $\left(4.6 \times 250 \mathrm{~mm}\right.$, flow rate of $0.7 \mathrm{ml} \mathrm{min}^{-1}$; Senshu, Tokyo, Japan), linear gradients started with $70 \% \mathrm{CH}_{3} \mathrm{CN}$ containing $\mathrm{D}_{2} \mathrm{O}$ and finished $100 \% \mathrm{CH}_{3} \mathrm{CN}$ in $30 \mathrm{~min}$, flow rate of $1 \mathrm{ml} \mathrm{min}^{-1}$ ).

Both one-dimensional ${ }^{1} \mathrm{H}$ - and ${ }^{13} \mathrm{C}$-NMR spectra were obtained on a Jeol A-400 (Jeol, Akishima, Tokyo, Japan) or a Varian Inova 500 NMR spectrometer 
(Varian), and two-dimensional COSY, NOESY, heteronuclear single-quantum coherence, CT-HMBC and J-resolved HMBC spectra were recorded on a Varian Inova 500 NMR spectrometer. Samples were dissolved in acetone- $d_{6}$ and the solvent peak was used as an internal standard $\left(\delta_{\mathrm{H}} 2.16\right.$ and $\left.\delta_{\mathrm{C}} 30.8\right)$. High-resolution FAB mass spectra were obtained using an LCT-premier XE mass spectrometer (Waters, Milford, MA, USA).

HPLC purifications were carried out using a Senshu Pak Pegasil ODS column $\left(20 \phi \times 250 \mathrm{~mm}\right.$, at a flow rate of $14 \mathrm{ml} \mathrm{min}^{-1}$; Senshu $)$ equipped with a Hitachi High Technologies L-2450 Diode array detector (Hitachi, Ibaraki, Japan). Merck silica gel $60 \mathrm{~F}_{254}$ plastic-backed sheets (Merck, Darmstadt, Germany) were used for TLC analysis. Preparative TLC was performed using Merck Si gel $60 \mathrm{~F}_{254}$ plastic-backed sheets.

\section{Cultivation of $S$. tumescens YM23-260}

S. tumescens YM23-260 was isolated from the sediments of Big drop-off of the Republic of Palau and is maintained at Marine Biotechnology Institute. It showed $99 \%$ homology to the type strain of $S$. tumescens. This strain was cultivated in $15 \mathrm{ml}$ test tubes each containing $5 \mathrm{ml}$ of a preliminary seed medium consisting of starch $1.0 \%$, polypeptone $1.0 \%$, molasses $1.0 \%$ and meat extract $1.0 \%(\mathrm{pH} 7.2)$. The test tubes were shaken on a reciprocal shaker (200 r.p.m.) at $28^{\circ} \mathrm{C}$ for 2 days. A total of $1 \mathrm{ml}$ aliquot of the seed culture was inoculated into each of the $500 \mathrm{ml}$ baffled Erlenmeyer flasks containing $100 \mathrm{ml}$ of the production medium consisting of starch $2.5 \%$, soybean meal $1.5 \%$, yeast extract $0.2 \%$ and $\mathrm{CaCO}_{3} 0.4 \%$ (pH 6.2). The fermentation was carried out at $28^{\circ} \mathrm{C}$ with agitation at 170 r.p.m. After 7 days, the fermentation broth was separated into mycelial cake and filtrate by suction filtration. The mycelial cake was dipped in $60 \%$ acetone for $2 \mathrm{~h}$ and the mycelium residue was removed by filtration. The extract was evaporated in vacuo to remove the acetone and the aqueous residue was extracted with EtOAc. The organic layer was dried over anhydrous $\mathrm{Na}_{2} \mathrm{SO}_{4}$ and evaporated to afford a brown oil (ca. $3 \mathrm{~g}$ from 101 of the fermentation broth).

\section{Purification of tumescenamides A (1) and B (2)}

The brown oil was subjected to Si gel column chromatography developed with $\mathrm{CHCl}_{3}$ and $\mathrm{MeOH}$ at 20:1 to give fractions containing 1 and 2. Both the fractions were combined and dried under reduced pressure. The dried material was finally purified by ODS HPLC. Detection of the compounds was carried out at UV $254 \mathrm{~nm}$. The column was eluted with $\mathrm{MeCN}$ in $\mathrm{H}_{2} \mathrm{O}$ (70\%) to give $\mathbf{1}$ and 2 in this order. These fractions were separately concentrated in vacuo to give pure $\mathbf{1}$ (white powder, $30.0 \mathrm{mg}$ ) and $\mathbf{2}$ (white powder, $2.5 \mathrm{mg}$ ).

\section{Determination of the amino acids and FA stereochemistry}

A sample of $1(6.0 \mathrm{mg})$ was hydrolyzed in $6 \mathrm{~N} \mathrm{HCl}$ at $140^{\circ} \mathrm{C}$ for $4 \mathrm{~h}$. After concentration to dryness, the residue was dissolved in $10 \mathrm{ml}$ of EtOAc- $\mathrm{H}_{2} \mathrm{O}$ (7:3). An amino-acid mixture was recovered in the aqueous layer and FA in the organic layer.

\section{Preparation and HPLC analysis of Marfey derivatives}

The aqueous layer was dried in vacuo and was added with $5 \% \mathrm{NaHCO}_{3}(500 \mu \mathrm{l})$ and FDAA (Marfey's reagent, $10 \mathrm{mg}$ ) in acetone $(500 \mu \mathrm{l})$. The mixture was heated on a bath at $70{ }^{\circ} \mathrm{C}$ for $3 \mathrm{~h}$. The reaction product was analyzed by HPLC as follows: Senshu Pak Pegasil ODS column $\left(20 \phi \times 250 \mathrm{~mm}\right.$, flow rate of $\left.0.7 \mathrm{ml} \mathrm{min}^{-1}\right)$, TFA mobile phase $(0.05 \%)$ consisting of $1 \%$ methanol in both A and B with $5 \%$ $\mathrm{MeCN}$ in $\mathrm{A}$ and $60 \% \mathrm{MeCN}$ in $\mathrm{B}$ (linear gradients started with $0 \% \mathrm{~B}$ and finished $100 \% \mathrm{~B}$ in $45 \mathrm{~min}$, flow rate of $1 \mathrm{ml} \mathrm{min}^{-1}$ ). Retention times of the standard FDAA derivatives were as follows: L-Thr $23.8 \mathrm{~min}$, D-Thr $27.8 \mathrm{~min}$, L-Tyr 29.2 min, D-Tyr $30.9 \mathrm{~min}$, L-Leu $31.4 \mathrm{~min}$, D-Leu $40.7 \mathrm{~min}$, L-Val $32.6 \mathrm{~min}$ and D-Val 36.9 min. The chromatograms of the hydrolysate derivatized with FDAA showed peaks corresponding to L-Thr, D-Tyr, L-Leu and L-Val.

Tumescenamide A (1). White powder; $[\alpha]^{25} \mathrm{D}^{+30}(\mathrm{c} 0.65, \mathrm{MeOH})$; UV $(\mathrm{MeOH})$ $\lambda_{\max }(\varepsilon) 277$ (1850), 224 (18900), IR (KBr) 3300, 1720, 1650, $1520 \mathrm{~cm}^{-1}$;
${ }^{1} \mathrm{H}-\mathrm{NMR}$ (500 MHz, acetone- $d_{6}$ ) and ${ }^{13} \mathrm{C}-\mathrm{NMR}\left(125 \mathrm{MHz}\right.$, acetone- $\left.d_{6}\right)$, see Table 1; HRFAB-MS $m / z 700.4248$ (calcd. for $\mathrm{C}_{37} \mathrm{H}_{58} \mathrm{~N}_{5} \mathrm{O}_{8},[\mathrm{M}+\mathrm{H}]^{+} 700.4279$ ).

Tumescenamide B (2). White powder; HRFAB-MS $m / z 742.4756$ (calcd. for $\mathrm{C}_{40} \mathrm{H}_{63} \mathrm{~N}_{5} \mathrm{O}_{8},[\mathrm{M}+\mathrm{H}]^{+}$742.4755). ${ }^{1} \mathrm{H}-\mathrm{NMR}\left(400 \mathrm{MHz}\right.$, acetone- $\left.d_{6}\right) \delta_{\mathrm{H}} 4.93(\mathrm{~d}$, 9.0, 3.2, Thr-2), 5.13, (dq, 3.2, 6.1, Thr-3), 1.34 (d, 6.1, Thr-4), 7.01 (d, 9.0, Thr NH), 6.59 (d, 7.0, ABA-3), 1.67 (d, 7.0, ABA-4), 8.01 (s, ABA NH), 4.43 (m, Tyr-2), 2.99 (dd, 13.7, 13.7, Tyr-3), 3.29 (dd, 3.4, 13.9, Tyr-3), 7.20 (d, 8.4, Tyr-5), 6.71 (d, 8.40, Tyr-6), 7.46 (d, 8.6, Tyr NH), 3.65 (dd, 3.9, 3.9, Val-2), 2.12 (m, Val-3), 0.86 (d, 7.1, Val-4), 0.58 (d, 7.1, Val-5), 8.02 (d, 3.9, Val NH), 4.30 (dd, 7.6, 7.6, Leu-2), 1.52 and 1.58 (m, Leu-3), 1.72 (m, Leu-4), 0.88 (d, 7.1, Leu-5), 0.98 (d, 6.6, Leu-6), 7.95 (br d, 2.0, Leu NH), 2.66 (m, FA-2), 0.97 and 1.72 (m, FA-3), 1.28 and 1.42 (m, FA-4), 0.78 and 1.12 (m, FA-5), 1.50 (CH, m, FA-6), 0.99 and $1.20\left(\mathrm{CH}_{2}, \mathrm{~m}, \mathrm{FA}-7\right), 1.22$ and $1.31\left(\mathrm{CH}_{2}, \mathrm{~m}, \mathrm{FA}-8\right), 0.84\left(\mathrm{CH}_{3}, \mathrm{~d}, 7.0\right.$, FA-9), $1.08\left(\mathrm{CH}_{3}, \mathrm{~d}, 6.8, \mathrm{FA}-2-\mathrm{Me}\right), 0.78\left(\mathrm{CH}_{3}, \mathrm{~d}, 6.3, \mathrm{FA}-4-\mathrm{Me}\right), 0.76\left(\mathrm{CH}_{3}, \mathrm{~d}\right.$, 6.5, FA-6-Me). ${ }^{13} \mathrm{C}$ NMR $\delta_{\mathrm{c}} 171.3$ (Thr-1), 55.5 (Thr-2), 75.1 (Thr-3), 16.2 (Thr-4), 165.2 (ABA-1), 128.3 (ABA-2), 134.8 (ABA-3), 14.7 (ABA-4), 169.3 (Tyr-1), 56.7 (Tyr-2), 36.6 (Tyr-3), 130.2 (Tyr-4), 130.9 (Tyr-5), 115.8 (Tyr-6), 156.8 (Tyr-7), 171.2 (Val-1), 61.7 (Val-2), 29.2 (Val-3), 19.2 (Val-4), 17.0 (Val-5), 176.6 (Leu-1), 54.4 (Leu-2), 40.7 (Leu-3), 25.2 (Leu-4), 22.3 (Leu-5), 22.9 (Leu-6), 177.1 (C, FA-1), 38.8 (CH, FA-2), $42.1\left(\mathrm{CH}_{2}\right.$, FA-3), $28.2(\mathrm{CH}, \mathrm{FA}-4), 45.6$ $\left(\mathrm{CH}_{2}, \mathrm{FA}-5\right), 30.2(\mathrm{CH}, \mathrm{FA}-6), 40.0\left(\mathrm{CH}_{2}, \mathrm{FA}-7\right), 20.5\left(\mathrm{CH}_{2}, \mathrm{FA}-8\right), 14.6\left(\mathrm{CH}_{3}\right.$, FA-9), $19.2\left(\mathrm{CH}_{3}, \mathrm{FA}-2-\mathrm{Me}\right), 21.0\left(\mathrm{CH}_{3}, \mathrm{FA}-4-\mathrm{Me}\right)$ and $20.3\left(\mathrm{CH}_{3}, \mathrm{FA}-6-\mathrm{Me}\right)$.

\section{Cell culture and bioassay for luciferase activity}

We used the reporter plasmid vector (pGL3 basic vector, Promega, Madison, WI, USA) in which the IDE promoter gene is inserted. ${ }^{12}$ COS7 cells were transfected with the IDE reporter gene and maintained in Dulbecco's modified Eagle medium supplemented with $10 \%$ fetal bovine serum, $50 \mu \mathrm{g}$ per ml streptomycin and 5 units per $\mathrm{ml}$ penicillin. For screening, $1 \mu \mathrm{l}$ of sample containing $4 \times 10^{4}$ cells was added into 96 multi-well plates and $100 \mu$ of the medium into each well. After incubation for $18 \mathrm{~h}$, the productivity of luciferase in each well was measured with Picagene BrillianStar-LT Luciferase assay system (Toyo B-Net, Tokyo, Japan) and a 2103 EnVision Multilabel Reader (Perkin-Elmer, Waltham, MA, USA).

1 Kuzuyama, T. \& Seto, H. Diversity of the biosynthesis of the isoprene units. Nat. Prod. Rep. 20, 171-183 (2003).

2 Motohashi, K. et al. Studies on terpenoids produced by Actinomycetes: oxaloterpins A, B, C, D, and E, diterpenes from Streptomyces sp. KO-3988. J. Nat. Prod. 70, 1712-1717 (2007).

3 Motohashi, K., Sue, M., Furihata, K., Ito, S. \& Seto, H. Terpenoids produced by Actinomycetes: napyradiomycins from Streptomyces antimycoticus NT17. J. Nat. Prod. 71, 595-601 (2008)

4 Furihata, K. \& Seto, H. Constant time HMBC (CT-HMBC), a new HMBC technique useful for improving separation of cross peaks. Tetrahedron Lett. 39, 7337-7340 (1998).

5 Matsumori, N., Murata, M. \& Tachibana, K. Conformational analysis of natural products using long-range carbon-proton coupling constants: three dimensional structure of okadaic acid in solution. Tetrahedron 51, 12229-12238 (1995).

6 Matsumori, N. et al. Long-range carbon-proton coupling constants for stereochemical assignment of acyclic structures in natural products: configuration of the C5-C9 portion of maitotoxin. Tetrahedron Lett. 37, 1269-1272 (1996).

7 Furihata, K. \& Seto, H. J-resolved HMBC, a new NMR technique for measuring heteronuclear long range coupling constants. Tetrahedron Lett. 40, 6271-6275 (1999).

8 Marfey, P. Determination of D-amino acids II. Use of a bifunctional reagent, 1,5-difluoro-2,4-dinitrobenzene. Carlsberg Res. Commun. 49, 591-596 (1984).

9 Vekrellis, K. et al. Neurons regulate extracellular levels of amyloid $\beta$-protein via proteolysis by insulin-degrading enzyme. J. Neurosci. 20, 1657-1665 (2000).

10 Farris, W. et al. Insulin-degrading enzyme regulates the levels of insulin, amyloid betaprotein, and the $\beta$-amyloid precursor protein intracellular domain in vivo. Proc. Natl Acad. Sci. USA 100, 4162-4167 (2003).

11 Farris, W. et al. Partial loss-of-function mutations in insulin-degrading enzyme that induce diabetes also impair degradation of amyloid beta-protein. Am. J. Pathol. 164, 1425-1434 (2004).

12 Yamada, N. et al. Genetic variation in the hypoxia-inducible factor- $1 \alpha$ gene is associated with type 2 diabetes in Japanese. J. Clin. Endocrinol. Metab. 90, 5841-5847 (2005). 